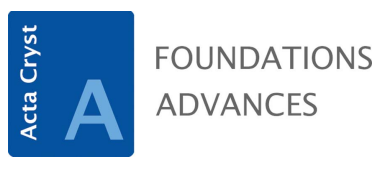

ISSN 2053-2733

\section{Twenty-Fourth General Assembly and International Congress of Crystallography, Hyderabad, India, 21- 28 August 2017}

Keywords: International Union of Crystallography; IUCr; General Assembly; International Congress of Crystallography.

Supporting information: this article has supporting information at journals.iucr.org/a

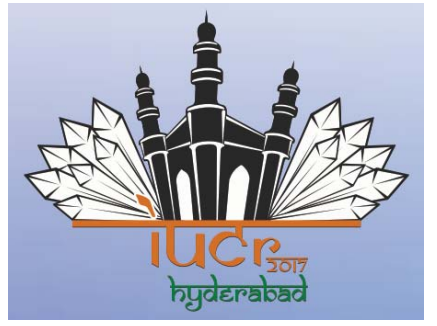

(C) 2020 International Union of Crystallography

\section{Introduction and Opening Ceremony}

By invitation of the Indian National Science Council, the Twenty-Fourth General Assembly and International Congress of Crystallography were held at the Hyderabad International Convention Centre, Hyderabad, India, 21-28 August 2017.

The meetings were attended by 1748 participants from 73 countries.

The General Assembly and Congress were opened at 5:00 p.m. on 21 August at the Congress Centre. Master of Ceremonies Dr R. K. R Jetti (Vice-Chair of the Local Organizing Committee) invited guests to participate in the lamp-lighting ceremony to open the Congress. Professor M. L. Hackert (President of the IUCr), Professor M. Glazer (Vice-President of the IUCr), Dr R. Chidambaram (Principal Scientific Advisor to the Government of India), Professor T. L. Blundell (Ewald Prize winner) and Professor G. R. Desiraju (Chair of the Local Organizing Committee) each lit a lamp. Welcoming addresses were made by Professor Desiraju, Dr Chidambaram, who was a member of the IUCr Executive Committee from 1990 to 1996 and Vice President of the IUCr from 1996 to 1999, and by Dr Rajiv Sharma (Secretary of the Department of Science and Technology of the Government of India). Professor Hackert, Dr Sharma, M. Heinz (Director of the Austrian Cultural Forum in New Delhi) and R. Krickl (creator) unveiled the world's largest crystal structure model.

Professor Hackert delivered the IUCr President's message and declared the meeting open. The Ewald Prize was awarded to Professor Blundell, who then presented the Ewald Award Lecture. The audience were then treated to a display of Indian vocal classical raga music by the Malladi Brothers. The evening ended with a welcoming reception.

\section{Twenty-Fourth International Congress}

\subsection{Scientific programme}

Three plenary lectures, 40 keynote lectures, 119 microsymposia and open commission meetings, five workshops, a software fayre, seven satellite meetings and 15 activities in the parallel programme (including a Dragons' Den session, exhibitions etc.) were held. An easy-to-use mobile app and attendee web site were available to serve as the platform for the real-time scientific programme. After registration, attendees could use this to maintain their own itinerary and view all scientific sessions, including abstract descriptions.

\subsection{Exhibitions}

A commercial exhibition comprising 58 companies and booksellers was organized.

\subsection{Social events}

Evening entertainments included a Bollywood-themed Congress banquet. Various excursions were also arranged.

\section{Minutes of the Twenty-Fourth General Assembly}

These minutes have been prepared by A. T. Ashcroft, Executive Secretary, under the authority of L. Van Meervelt, General Secretary and Treasurer of the IUCr and Secretary of the General Assembly. 


\subsection{Introduction and list of delegates}

Sessions of the General Assembly were held on the evenings of Tuesday 22 August, Wednesday 23 August and Saturday 26 August. The following attendance list gives the names of official delegates appointed by the Adhering Bodies (see Appendix D in the supporting information) and the alternates who substituted at one or more sessions. Dates of attendance are given in parentheses for those who were not present at every session. The names are listed by the countries to which the respective Adhering Bodies belong, and the number of votes of the Adhering Body is given in parentheses after the name of the country. The names of the Chairs of the delegations are given in bold where they are known; those of alternates are marked by an asterisk. There were no delegates from Greece, the Regional Committee of Crystallographers from Latvia and Ukraine, or Serbia.

Albania/Kosovo (1): D. Siliqi

Algeria (1): N. Benali-Cherif (22 and 26 August)

Argentina (1): D. G. Lamas

Australia (3): M. Parker, H. Maynard-Casely, C. Ling

Austria (1): K. Hradil

Bangladesh (1): A. Hussain

Belgium (2): J. Hadermann, D. Maes

Brazil (1): I. M. Carvalho de Abreu Fantini

Bulgaria (1): M. I. Aroyo

Cameroon (1): I. Tonle Kenfack

Canada (3): L. Dawe, P. Grochulski, T. Friscic (23 and 26

August), P. Mercier* (22 August)

Chile (1): M. Fuentealba

China, People's Republic of (4): Xiao-Dong Su, Dachuan Yiu, XiaoXia Du, Song Gao (22 August), Tian Qiong Ma* (23 and 26 August)

China, The Academy of Sciences Located in Taipei (2):

C.-J. Chen, C.-H. Lee

Costa Rica (1): A. Araya

Croatia (1): M. Daković (22 August)

Czech/Slovak Republics (2): P. Mikulik, I. K. Smatanova (23 August), J. Moncol* (22 and 26 August)

Denmark (1): J. Overgaard (23 August), J.-E. Jørgensen* (22 and 26 August)

Egypt: G. S. Kamel

Finland (1): K. T. Rissanen (23 and 26 August)

France (4): S. Ravy, J.-P. Itié, R. Guinebretière, P. Guionneaau

Germany (4): S. Schorr, D. Többens, U. Kolb, W. Schmahl (23 and 26 August), C. Lehmann* (22 August)

Hungary (1): P. Bombicz

India (3): S. C. Mande (26 August; refused entry to Congress Centre 22 and 23 August due to non-payment of registration fee), D. Pandey, R. Sankaranarayanan (present 22 and 26 August; boycotted 23 August)

Ireland, Republic of (1): P. McArdle (22 and 23 August)

Israel (1): L. Meshi

Italy (3): G. Zanotti, F. Boscherini, A. Zappettini

Japan (4): A. Nakagawa, T. Kamiyama, H. Uekusa, G. Kurisu
Korea (1): M. S. Lah (22 and 23 August), T. S. Yoon* (26 August)

Mexico (1): J. Reyes Gasga

Morocco (1): D. Zakaria

The Netherlands (2): M. Lutz, B. Schierbeek (22 and 26 August)

New Zealand (1): C. Squire

Norway (1): C. H. Görbitz

Poland (1): W. Paszkowicz

Portugal (1): J. Rocha (22 and 23 August)

Regional Committee: Indonesia/Malaysia/Thailand/

Vietnam (1): S. Adams (22 and 23 August)

Russia (5): O. A. Alekseeva, E. V. Antipov (22 and 23 August), A. E. Blagov, Y. A. Dyakova, A. L. Vasiliev (23 and

26 August), R. A. Senin* (22 and 26 August)

Singapore (1): J. J. Vittal

Slovenia (1): D. Turk (26 August)

South Africa (2): D. G. Billing, C. Esterhuysen

Spain (3): F. Lahoz, E. Molins, F. Gandara

Sweden (2): Xiao-Dong Zou, S. Lidin

Switzerland (2): P. Macchi, A. Linden

Tunisia (1): M. Oumezzine

Turkey (1): S. Ide (23 and 26 August)

UK (5): L. Brammer, R. Cooper, S. J. Coles (22 and 26 August), A. Stanley (23 August), E. Garman, A. Maloney* (22 August), G. Rosair* (23 and 26 August)

Uruguay (1): L. Suescun (22 and 26 August), J. A. Imelio* (23 August)

USA (5): J. Ng, C. Lind-Kovacs, A. Sarjeant (22 and 26 August), B. Campbell, S. Byram, I. Guzei* (23 August)

Venezuela (1): G. Diaz de Delgado

Present as members of the Executive Committee: M. L. Hackert (President), M. Glazer (Vice-President), L. Van Meervelt (General Secretary and Treasurer), G. R. Desiraju (Immediate Past President), H. A. Dabkowska, W. Depmeier, J. M. Guss, R. Kuzel, S. Garcia-Granda, M. Takata (Ordinary Members). M. H. Dacombe and A. T. Ashcroft were in attendance as outgoing and incoming Executive Secretary, respectively.

Representatives (non-voting) from the Regional Associates were seated with the delegates.

\subsection{First Session, Tuesday 22 August 2017, 7:00 p.m.}

(1) Introductory remarks by the President

Professor Hackert welcomed the delegates and observers, reviewed the financial state of the Union over the past triennium and emphasized that although the income from the publications remained strong and represented $86 \%$ of the Union's income, it would be important to find additional supplementary sources of income in the coming triennium. The President requested the delegates to approve two new items on the agenda.

(2) Procedural matters

In order to verify the list of voting delegates, the President requested the General Secretary to read this list, and asked delegates to indicate their presence when their names were 
called. Delegates were also asked to complete an attendance form.

Two delegates, one from Israel and one from Uruguay, were appointed to act as tellers when votes had to be counted during the Assembly.

After being used successfully in Montreal, electronic voting would be again be used for secret ballots.

(3) Approval of agenda

The agenda and appendices to the agenda had been distributed to Secretaries of National Committees in June 2017. The agenda, including the two new items [numbers (12) and (15)], were approved.

(4) Amendments to Statutes and By-Laws affecting adherence to the Union

The President reported that there were no proposals.

(5) Applications for membership of the Union

Applications for membership of the IUCr had been received from Albania and Kosovo (Category I), Bangladesh (Category I), Singapore (Category I), and Tunisia (Category I).

The applications were all accepted by the General Assembly.

(6) Withdrawal of Adhering Bodies

(a) Chile. The subscriptions due from the Adhering Body in Chile, Comisión Nacional de Investigación Cientifica y Tecnólgica, had not been paid for the years 2009, 2010, 2011 and 2012. Accordingly, the membership of the Adhering Body for Chile had been automatically suspended in February 2013, in accordance with Statute 9.6. At the meeting in Montreal in 2014, the President had indicated that the General Assembly could either confirm the withdrawal of Chile (in which case the membership arrears would be written off and Chile could reapply for membership in 2017) or allow the suspension of the membership to continue until such time as the arrears could be paid. The General Assembly had decided that the suspension of the Adhering Body for Chile should be continued until such time as the community in Chile could reorganize itself and pay its arrears. Shortly before the Congress, payment was received for 2009-2012, so Chile became eligible for reinstatement, and the General Assembly voted to reinstate Chile.

(b) Regional Committee of Crystallographers from Latvia and Ukraine. The Adhering Body had given notice of withdrawal from membership of the Union, in accordance with Statute 3.10. The Executive Committee recommended that the membership should be allowed to run down until the Regional Committee was automatically suspended and membership allowed to lapse. The General Assembly voted to approve this recommendation.

(7) Changes in names of Adhering Bodies

The change in name of the Adhering Body of Portugal from the Sociedade Portuguesa de Fisica to the Sociedade Portuguesa de Química was approved.

The change in name of the Adhering Body of Chile from the Comisión Nacional de Investigación Cientifica y Tecnólgica to the Asociación Chilena de Cristalografia was approved.

The change in name of the Adhering Body of the Regional Committee of Crystallographers from Bangladesh, Indonesia,
Malaysia, Singapore, Thailand and Vietnam to the Regional Committee of Crystallographers from Indonesia, Malaysia, Thailand and Vietnam was accepted by the General Assembly.

(8) Changes in category of adherence of Adhering Bodies

The President reported that no application for a change in category of adherence had been received.

(9) Approval of minutes of Twenty-Third General Assembly

The minutes, which were contained in the published report of the Twenty-Third General Assembly and International Congress of Crystallography [Acta Cryst. (2016), A72, 85-167], were approved and two copies were signed by the President and the General Secretary, in accordance with By-Law 1.13. There were no matters arising from the minutes.

(10) Amendments to Statutes and By-Laws not affecting adherence to the Union

The President reported that there were no proposals.

(11) Report of Executive Committee

The report of the Executive Committee on the activities of the IUCr since the Twenty-Third General Assembly had been submitted to the National Committees and the Commissions in June 2017, in accordance with Statute 6.8, and is available as Appendix A1 in the supporting information.

The President praised the Executive Outreach Officer for a remarkably successful International Year of Crystallography (IYCr) programme and the creation of the Education and Outreach Fund to build on the legacy of IYCr. The President also congratulated the outgoing Executive Secretary on his retirement and thanked him for his years of outstanding service to great applause from the delegates. The incoming Executive Secretary was welcomed.

(12) Gender equality

The President reminded the delegates that there had been concern a few years ago about insufficient geographical diversity in the IUCr, which had resulted in a great deal of effort to improve this. He also reminded delegates that in his Newsletter articles since his election he had repeatedly stressed the need to promote all forms of diversity: geographical, age, academic discipline and, of course, gender. The Executive Committee were acutely aware of both the problem of the lack of gender balance at the present Congress and the level of concern amongst the crystallographic community about this. Consequently, the President presented a statement on gender diversity that had been approved by the Executive Committee and requested that the General Assembly endorse this:

The International Union of Crystallography strives to achieve gender balance in all its institutions and activities bearing in mind other diversity needs and its existing obligations to geographic and academic discipline representation where appropriate.

To achieve this aim the IUCr will adopt procedures to promote gender balance in respect of all of its activities including selection of candidates for positions on its Committees and Commissions. Those seeking support from the Union for Congresses, meetings, workshops and schools will also have to demonstrate their efforts to address gender balance.

The General Assembly voted to approve the statement but delegates urged the Executive Committee to ensure that this 
was being enforced. The Executive Committee were also requested to ensure that gender-balance statistics for all IUCrsponsored meetings were made public.

(13) Financial report

A financial report, covering the calendar years 2014, 2015 and 2016, had been prepared by the Treasurer and had been submitted to the National Committees and the Commissions in June 2017. The report is available as Appendix A2 in the supporting information.

The Treasurer reported the composition of the Finance Committee. The Union operated in three currencies: member subscriptions were largely paid in CHF; one-third of the investments, most of the income and most expenses were in GBP; and two-thirds of the investments and some expenses were in USD. The accounts had to be prepared in CHF, which meant that a strong Swiss franc reduced the value of the assets given in the accounts when expressed in CHF. From the next triennium accounts will be presented in USD as allowed by Swiss law.

The Treasurer presented graphs showing a steady drop in income, along with a rise in expenditure due to IYCr (more events and recruitment of extra staff), which had then been reduced by cost-cutting measures but had still resulted in an operating loss for four consecutive years. The reduction in income was due to fewer articles being published and reduced income from investments. The Treasurer reported that losses were shrinking and he was hopeful that there would not be a deficit for much longer.

The annual turnover was about CHF 5000 000, and assets at this level were required. The intention was to make a small profit so that the services provided to crystallographers through the Research and Education Fund, the President's Fund and the Ewald Fund could be maintained and developed. The Finance Committee had implemented measures to improve the situation, with the aim of saving USD 250000 per year, including launching the Associates Programme, increasing open-access fees, obtaining grants from ICSU to support outreach activities and reducing editorial honoraria. The Business Development Manager was also being encouraged to generate new advertising income and raise funds from charitable bodies. New arrangements with future Congress organisers would also increase the profitability of Congresses for the IUCr.

(14) Ewald Prize

Details of the prize, awarded to Professor T. Blundell at the Opening Ceremony, and the citation are given in Appendix A3 in the supporting information.

(15) Bragg Prize

The Vice-President presented a proposal from the Executive Committee to initiate a new prize commemorating W. H. and W. L. Bragg to recognise scientists in the early stages of their careers. The value of the prize was intended to be smaller than the Ewald Prize and financed by private money, some of which had already been donated. After a lively discussion about how 'early stage' could be defined, it was agreed that the motion to create the prize be approved so that it could be awarded at the next Congress, but that the criteria for 'early stage' be defined in the interim and discussed at the next General Assembly.

\section{(16) International Year of Crystallography}

The Executive Outreach Officer (M. Zema) was thanked again by the President for all he had done for the Union. Dr Zema was keen to stress the contributions of others to the IYCr, including the past and present Executive Committees, current and past Presidents, and the staff in Chester. The Outreach Officer also stressed the contributions of many volunteers around the globe. While it was impossible to report all of the activities, the IYCr web site was still running and showed more than 500 events; many others were also held. The IYCr activities had expanded the geography of crystallography, so the increase in the numbers of applications for membership of the IUCr were also an outcome of the IYCr.

The Outreach Officer showed graphs of the main activities for the IYCr in the main target regions of Africa, South East Asia and Latin America, including Open Labs in many different countries and three Summit meetings. The Closing Ceremony was very successful; it was held in Rabat, Morocco, as the proposal to hold the IYCr had come from Morocco and the IUCr wanted to acknowledge this by holding the ceremony there. The final resolution for the IYCr, 'Crystallography for the Next Generation', was to create a legacy, and this has been signed up to by all the delegates present at the ceremony and by many others afterwards. The resolution was also undersigned by the Presidents and/or Directors of numerous international institutions, including UNESCO, ICSU, TWAS, IUPAC, IUPAP, IUBMB and IMA. The Outreach Officer stressed the need to build on the success of the IYCr, and the necessity of finding the finances to do that. The IYCr was the first International Year to have received no funding from UNESCO, so all the funding had come from the IUCr and from a fundraising campaign with sponsors. In order for the outreach activities to continue, crystallographers were encouraged to publish in IUCr journals and to join the Associates Programme, as those were the routes by which the IUCr could raise the funds to continue to support this.

The Outreach Officer reported that an ICSU grant of USD 30000 had been obtained to build outreach in Africa, and the first pan-African crystallography conference had resulted. A second grant from ICSU had been obtained in partnership with IUPAP for EUR 300000 on Utilization of Light Source and Crystallographic Sciences to Facilitate the Enhancement of Knowledge and Improve the Economic and Social Conditions in Targeted Regions of the World.

\section{(17) IUCr Associates Programme}

The Business Development Manager (J. Agbenyega) described the new programme and how it was hoped it would both bring crystallographers together and raise funds for the IUCr to continue its education and outreach activities. He also described other activities designed to increase the IUCr's revenue, including new advertising opportunities, webinars and funding applications.

The President then adjourned the session at 9:30 p.m. 
3.3. Second Session, Wednesday 23 August, 2017, 7:00 p.m.

(18) Commission on Journals

The report of the Commission on Journals had been distributed to the National Committees and the Commissions in June 2017, and is given in Appendix A6.1 in the supporting information.

As the Editor-in-chief had not been able to obtain a visa to travel to India, the Executive Managing Editor (P. R. Strickland) addressed the General Assembly. He remarked that the IUCr has been publishing data with articles since 1991, and other publishers have only recently started to copy this, and that the IUCr journals were able to do this due to the introduction of the Crystallographic Information File (CIF) specification in the early 1990s. In the last triennium, the IUCr journals had been trying to increase their influence and broaden their scope in order to cover all of the topics being covered by the Commissions, but there was still some work to do on that. The IUCr staff were also doing work on behalf of their authors to publicise their articles once they are published.

In the last triennium, IUCr journals had published more than 20 special issues and had also commissioned many individual articles, such as topical reviews, lead articles and feature articles. The plan was to continue with this as they had been generally well cited and helped the journals to improve their impact factors. IUCr journals had also started to publish commentaries on papers, and authors who had received this extra service had been pleased with this.

The Executive Managing Editor concluded by reminding the delegates that if they value the IUCr they should send their best papers to IUCr journals. He thanked all the authors, editors and reviewers, and stated that it was a pleasure to work for the Union and to come to the conference to meet editors and reviewers.

The President reminded the delegates that this is their Union, and that the idea of the Union was to set standards and to create publications in which to publish crystallographers' work.

E. Garman thanked the staff in Chester, a sentiment that was seconded by M. Weiss, who also questioned the lack of an Open Commission on Journals Meeting at this Congress.

The report was accepted by the General Assembly.

(19) Commission on International Tables

The report by the Chair of the Commission on International Tables had been distributed to the National Committees and the Commissions in June 2017, and is available in Appendix A6.2 in the supporting information.

The Chair (Professor C. P. Brock) summarized the status of all the volumes and reported that a new Volume H, Powder Diffraction, would be available in late 2017 or early 2018 and would have electronic appendices. Volume I was described as being under intense development since the last triennium, and Professor Brock informed the delegates that the Commission on Magnetic Structures had an outline for a new volume. She thanked M. I. Aroyo for the fantastic job he had done in getting the new edition of Volume A published.
Professor Brock reminded the delegates that while the volumes on symmetry did not change very quickly, the later handbook volumes were very time sensitive, with a danger of being out of date by the time they were published. The other volumes were described as being somewhere in between. Professor Brock stated that, in light of this, a proposal was under consideration for putting contributions for new and revised volumes online before the whole volume was published. She advised the delegates that this would not apply to Volumes A, A1 or E, and would be most useful for Volumes $\mathrm{F}$ through I (on XAFS). This would provide an advantage for authors who were prompt, and would prevent them from being irritated when volumes took longer than planned to publish. Professor Brock emphasized that this would not happen without the agreement of the office in Chester and the editors of that volume. She informed the delegates that this proposal had been presented to the Executive Committee the day before, and that they were happy for further discussions to take place. She urged any delegates with views on this to let her or Professor M. Glazer know. She concluded by saying that nothing could be done without the staff in the Chester office and that the editors were fantastic, and put a great deal of their energy into the series for little reward.

The General Assembly accepted the report.

(20) Committee for the Maintenance of the CIF Standard

The report of the Chair of the Committee for the Maintenance of the CIF Standard (COMCIFS) had been distributed to the National Committees and the Commissions in June 2017 and is given in Appendix A7 in the supporting information.

(21) IUCr Newsletter

The report of the Editors of the IUCr Newsletter had been distributed to the National Committees and the Commissions in June 2017 and can be found in Appendix A8 in the supporting information.

The President reported that production of the Newsletter would be moving to the office in Chester, and the format would change. He advised that much was still under discussion, but that different regional advertisers in different versions of the same Newsletter could be a possibility, and that the Newsletter might appoint Regional Editors.

W. L. Duax was thanked in his absence.

(22) Diffraction Data Deposition Working Group

The Chair of the Working Group (Professor J. R. Helliwell) encouraged the General Assembly to attend the keynote lecture on the following day for more detail of the work of the Group, but said that the findings of the Group would be confidential until released by the Executive Committee.

The Group strongly suggested having a checkCIF service for raw data to ensure that the IUCr was compliant with FAIR (Findable, Accessible, Interoperable, Reusable) principles for archived data, and to ensure that experimental variables were always included in diffraction data sets. The Group would transition into a standing Committee for Data (ComDat), and would meet the ICSU requirement that each Union should have a designated body that deals with data. ComDat would 
also include database representatives, Commission members and consultants.

(23) IUCr/Oxford University Press Book Series Committee

Owing to the sad loss of D. Viterbo there was no Chair of the Committee. The President reported that no books had been published in 2016 or 2017, but Crystal Clear, a biography of Lord and Lady Bragg by M. Glazer, was published in 2015. A new Chair would be appointed at the meeting of the new and old Executive Committees on 27 August.

(24) Non-publishing Commissions

The reports of the Commissions on their activities since the Twenty-Third General Assembly had been distributed to the National Committees and the Commissions in June 2017. The reports are given in Appendix A6 in the supporting information.

The President reported that the Executive Committee had held in-depth discussions with the Chairs.

The General Assembly accepted all the reports.

(25) Proposals for new Commissions

The Executive Committee had established an ad interim Commission on Crystallography of Materials in July 2012, and the General Assembly in Montreal in 2015 had accepted the recommendation of the Executive Committee that the Commission should continue with an ad interim status until the next Congress, when its status would be reviewed. The Executive Committee recommended removing the ad interim status and making it a full Commission. This recommendation was accepted by the General Assembly.

Professor H. Dabkowska informed the General Assembly that a Commission on Space Science was due to be proposed by Professor J.-M. Garcia-Ruiz after a successful workshop in Puebla, Mexico, but Professor Garcia-Ruiz had been unable to attend the Congress for personal reasons, so the proposal would be delayed and there would be a Congress session about this on 27 August instead. The community were requested to provide feedback to determine whether a formal proposal would be made at the next Executive Committee meeting.

(26) Review of existing Commissions

The President reported that the Executive Committee had considered the work of the Commissions and recommended that the name of the Commission on Charge, Spin and Momentum Density should be changed to Commission on Quantum Crystallography, as recommended by the Commission.

The General Assembly approved the change of name to Commission on Quantum Crystallography.

(27) Determination of number of elected members on each Commission

In accordance with Statute 5.10(d) (see Appendix B in the supporting information), the Assembly had to determine the number of persons to be elected on the Commissions until the Twenty-Fifth General Assembly; these numbers did not include Chairs, Co-editors or ex officio members. The numbers of elected members approved by the General Assembly (Chairs not included) are set out below:
1. Commission on Journals 0

2. Commission on International Tables 0

3. Commission on Aperiodic Crystals 8

4. Commission on Biological Macromolecules 13

5. Commission on Crystal Growth and Characterization of 8 Materials

6. Commission on Crystallographic Computing 8

7. Commission on Crystallographic Nomenclature 0

8. Commission on Crystallographic Teaching 8

9. Commission on Crystallography in Art and Cultural 7 Heritage

10. Commission on Crystallography of Materials 7

11. Commission on Electron Crystallography 9

12. Commission on High Pressure 9

13. Commission on Inorganic and Mineral Structures 9

14. Commission on Magnetic Structures 9

15. Commission on Mathematical and Theoretical 10 Crystallography

16. Commission on Neutron Scattering 8

17. Commission on NMR Crystallography and Related Methods 8

18. Commission on Powder Diffraction 9

19. Commission on Quantum Crystallography 9

20. Commission on Small-Angle Scattering 7

21. Commission on Structural Chemistry 9

22. Commission on Synchrotron and XFEL Radiation 9

23. Commission on XAFS 9

(28) Reports of Representatives on Regional and Scientific Associates

In accordance with Statute 8.5, the reports of the Representatives on Regional and Scientific Associates had been circulated with the agenda papers in June 2017 . These reports are available in Appendix A12 in the supporting information.

All the reports were accepted.

(29) Reports of Representatives on bodies not belonging to the Union

In accordance with Statute 8.5, the reports of the Representatives had been circulated with the agenda papers in June 2017. These reports are given as Appendix A13 in the supporting information.

All the reports were accepted.

(30) Sponsorship of meetings: Sub-committee on the Union Calendar

The report of the Chair had been distributed to the National Committees and the Commissions in June 2017 and is given in Appendix A11 in the supporting information.

The Committee was thanked for its hard work.

(31) Date and place of Twenty-Fifth General Assembly

The Twenty-Fifth General Assembly would be held in Prague, Czech Republic, August 2020, at the invitation of the Czech and Slovak Crystallographic Association.

(32) Determination of date and place of Twenty-Sixth General Assembly

In accordance with By-Law 1.3 the General Assembly could determine the place of the next but one General Assembly, 
namely the Twenty-Sixth General Assembly to be held in 2023. The President announced that invitations had been received from the Society of Crystallographers in Australia and New Zealand (SCANZ) to hold the Congress in Melbourne, Australia, and from the American Crystallographic Association (ACA) and the National Academy of Science of the USA to hold the Congress in San Diego, USA. He reported that the Executive Committee had considered the applications and found them to be in order. M. Parker presented the formal invitation for SCANZ and J. $\mathrm{Ng}$ presented the formal invitation for the ACA. A decision on which invitation to accept was delayed until the next session to give the delegates time to consider the choice [see Minute (33)]. Although they did not wish to be considered as hosts for the Twenty-Sixth General Assembly, there was a further presentation from D.-C. Yin from Xi'an City in China.

The President adjourned the session at 10:15 p.m.

\subsection{Third Session, Saturday 26 August 2017, 7:00 p.m.}

(33) Determination of date and place of Twenty-Sixth General Assembly (continued)

The General Assembly accepted the invitation to hold the Twenty-Sixth General Assembly in 2023 in Australia.

(34) Determination of general policy and timetable for period to Twenty-Fifth General Assembly

There were no comments on this item.

(35) Preliminary consideration of activities for period 20202023

There were no comments on this item.

(36) Budget estimates for period to Twenty-Fifth General Assembly: determination of unit contribution

These budget estimates had been distributed with the agenda papers and are given as Appendix A14 in the supporting information.

The General Assembly accepted the budget estimates and approved the recommendation of the Executive Committee to continue the unit contribution unchanged, at CHF 1000, for the years 2018, 2019 and 2020.

(37) Confirmation of appointments of Editors of publications of the Union

In accordance with Statute 7.1, the initial appointments and the reappointments of the Editors of the publications of the IUCr were made by the Executive Committee and were subject to confirmation by the General Assembly.

The Assembly confirmed the following appointments and reappointments:

Editor-in-chief of IUCr Journals: S. S. Hasnain (UK)

Editor of Section A of Acta Crystallographica: S. J. L. Billinge (USA)

Editors of Section B of Acta Crystallographica: A. J. Blake (UK), M. de Boissieu (France) and A. Nangia (India)

Editors of Section $C$ of Acta Crystallographica: L. R. Falvello (Spain), P. R. Raithby (UK) and J. White (Australia)

Editors of Section D of Acta Crystallographica: J. L. Martin (Australia) and R. J. Read (UK)
Editors of Section $E$ of Acta Crystallographica: E. V. Boldyreva (Russia), C. Massera (Italy), H. Stoeckli-Evans (Switzerland) and L. Van Meervelt (Belgium)

Editor of Section F of Acta Crystallographica: M. J. van Raaij (Spain)

Editors of Journal of Applied Crystallography: A. J. Allen (USA), J. Hajdu (Sweden) and G. J. McIntyre (Australia)

Editors of Journal of Synchrotron Radiation: Y. Amemiya (Japan), M. Eriksson (Sweden) and I. Schlichting (Germany)

Editors of IUCrJ: D. Argyriou (Sweden), E. N. Baker (New Zealand), C. R. A. Catlow (UK), G. R. Desiraju (India) and J. C. H. Spence (USA)

Editors of IUCrData: W. T. A. Harrison (UK), J. Simpson (New Zealand), H. Stoeckli-Evans (Switzerland), E. R. T. Tiekink (Malaysia), L. Van Meervelt (Belgium) and M. Weil (Austria)

General Editor of International Tables: C. P. Brock (USA) Editor of Volume A: M. I. Aroyo (Spain)

Editors of Volume B: G. Chapuis (Switzerland) and M. Dusek (Czech Republic)

Editor of Volume C: T. R. Welberry (Australia)

Editor of Volume D: A. Authier (France)

Editor of Volume E: D. B. Litvin (USA)

Editors of Volume F: M. G. Rossmann (USA), E. Arnold (USA) and D. M. Himmel (USA)

Editors of Volume G: B. McMahon (UK) and J. Hester (Australia)

Editors of Volume H: C. J. Gilmore (UK), J. A. Kaduk (USA) and H. Schenk (The Netherlands)

Editors of Volume I: C. T. Chantler (Australia), F. Boscherini (Italy) and B. A. Bunker (USA)

Editor of Volume A1: U. Müller (Germany)

(38) Election of Chairs and members of Commissions

The nominations made by the Executive Committee for the Chairs and members of Commissions, after consultation with the Commissions through their Chairs, had been notified to delegates.

Since no other nominations had been made by the delegates, the persons recommended by the Executive Committee were considered elected.

The current full memberships of all the Commissions, including the ex officio members, together with the addresses of the Chairs, are given as Appendix $\mathrm{C}$ in the supporting information.

(39) Election of Representatives on bodies not belonging to the Union and on Regional and Scientific Associates

The nominations made by the Executive Committee for those Representatives to be elected by the General Assembly had been notified to delegates. As no other nominations were made, these persons were considered elected.

The names and addresses of the Representatives of the Union, including those appointed ex officio, are given in Appendix $\mathrm{C}$ in the supporting information.

(40) Election of Officers of the Union

The nominations made by the Executive Committee for Officers of the Union had been included in the agenda papers distributed in June 2017. S. Banerjee (India), W. Depmeier 
(Germany), A. M. Glazer (UK) and S. Lidin (Sweden) were nominated for President. In addition to the Executive Committee nominations (and in accordance with By-Law 8.2), J. R. Helliwell (UK) was nominated for President by six delegates to the General Assembly. H. A. Dabkowska (Canada) and M. R. N Murthy (India) were nominated for Vice-President and L. Van Meervelt (Belgium) was nominated for General Secretary and Treasurer. Eleven nominations were made for the three six-year vacancies for Ordinary Members: D. Billing (South Africa), G. Diaz de Delgado (Venezuela), P. Grochulski (Canada), K. A. Kantardjieff (USA), P. Karthe (India), K. Lawniczak-Jablonska (Poland), J. L. Martin (Australia), S. Ravy (France), M. Takata (Japan), A. E. Voloshin (Russia) and M. S. Weiss (Germany). The same eleven nominations were made for the one three-year vacancy for an Ordinary Member (if necessary). Prior to the Congress, K. Kantardjieff withdrew from the elections. As there was only one candidate for General Secretary and Treasurer this candidate was considered elected. Elections for the President, Vice-President, three Ordinary Members for the normal sixyear term and one vacancy for a three-year term were held by secret ballot. The following nominees were elected:

President

S. Lidin (Sweden)

Vice-President

H. Dabkowska (Canada)

General Secretary and Treasurer

L. Van Meervelt (Belgium)

Ordinary Members (six years)

G. Diaz de Delgado (Venezuela)

\section{J. L. Martin (Australia)}

M. Takata (Japan)

The President congratulated the new members of the Executive Committee and thanked those who would be retiring. The delegates were also thanked and applauded for their contribution. A. Linden (Switzerland) called on the delegates to thank M. Dacombe, who was standing down as Executive Secretary. The delegates responded with a standing ovation.

(41) Any other business

As there was no other business, the President declared the Twenty-Fourth General Assembly closed at 10:15 p.m.

\section{Closing Ceremony, Monday 28 August 2017}

G. R. Desiraju (Chair of the Local Organizing Committee) presented a short review of the Congress and thanked all who had worked so hard. Poster prizes were presented.

M. L. Hackert (outgoing President) thanked the organizers for making the Congress such a success and spoke warmly about the IUCr. He thanked the retiring and the continuing members of the Executive Committee for their work and welcomed the new members.

S. Lidin (incoming President) provided words of encouragement about the future of the IUCr and his pleasure at being a part of it.

R. Kuzel (Chair of the Local Organizing Committee for the next Congress) invited everyone to Prague in 2020.

M. L. Hackert declared the Twenty-Fourth Congress and General Assembly to be closed. 